Brit. J. prev. soc. Med. (1966), 20, 181-188

\title{
RESPONSE TO A QUESTIONNAIRE ON CHRONIC BRONCHITIC SYMPTOMS IN EAST ANGLIA
}

\author{
BY \\ G. R. McNAB, E. J. SLATOR, AND C. J. STEWART \\ Chest Physicians, East Anglian Regional Hospital Board
}

The prevalence of chronic bronchitis has been shown to be greater in urban than in rural areas (Higgins, Cochrane, Gilson, and Wood, 1959; College of General Practitioners, 1961), but chest physicians in East Anglia were of the opinion that chronic bronchitis was more prevalent in their rural areas than had hitherto been believed. In 1961 the Chest Diseases Advisory Committee recommended to the Research Committee of the East Anglian Regional Hospital Board that a survey be carried out to determine and compare the prevalence of symptoms of chronic bronchitis in different areas of the region.

The symptom complex of chronic bronchitis has been variously defined. In 1960 the Medical Research Council Committee on the aetiology of bronchitis issued a "Questionnaire on Respiratory Symptoms" in which it was inferred that "persistence of cough, productive of sputum, on most days for 3 months each year" was, in the absence of other known cause, indicative of chronic bronchitis.

The East Anglian Survey reported here used this criterion to estimate the prevalence of chronic bronchitis. The results are compared with other surveys.

The survey obtained information on the following points:

(1) The degree of co-operation from householders in returning letters of inquiry.

(2) The accuracy of a written self-applied questionnaire on respiratory symptoms compared with a similar questionnaire applied later by a doctor at a clinical interview.

(3) The comparison of a clinical diagnosis of "chronic bronchitis" with a diagnosis based on symptoms alone.
(4) The prevalence of chronic bronchitis in East Anglia.

\section{MeTHOD}

The survey was carried out in 1962. The months of March and April were chosen because memories of winter illness would be fresh. The survey was restricted to men in the age group 55-64 years, so that comparison could be made with previously reported surveys. Three districts were chosen:

(1) The industrial part of Peterborough,

(2) An inland rural area centred on the country town of Halesworth about 30 miles from Ipswich and Norwich,

(3) A strip along the North Norfolk coast including the small non-industrial towns of Cromer, Sheringham, and Holt.

From the electoral rolls of these areas addresses were chosen at random (Appendix A). To each selected address an explanatory letter was sent with two copies of a questionnaire and a stamped addressed envelope for reply. This letter was printed on the headed writing paper of the clinic or hospital concerned and each was signed individually by the doctor who controlled the Survey in each area. This gave a personal touch which we believecontributed materially to the high response rate. The letter described the need for research into the prevalence of bronchitis; how the household had been chosen to receive the letter; and the need for those without symptoms as well as those with symptoms to reply. It also asked if there were any men aged 55-64 years living in the house; this was to be indicated by placing a cross in the appropriate square. If there was no male of the age group in the house it was asked that the letter be returned. The number of letters returned was a 
measure of the degree of co-operation. All men in the age group in each household were asked to complete a questionnaire (Appendix B) which asked five questions about cough, five about phlegm production, and finally whether the person would be willing to attend a Chest Clinic for $x$-ray. The questionnaire was based on questions one to ten of the Medical Research Council's "Questionnaire on Respiratory Symptoms, 1960", which deal with cough, sputum, and their duration. Altogether 1,600 letters and questionnaires were sent to households in each area. They were sent out in batches of 200 at weekly intervals. If after 2 weeks no reply had been received, the household was sent a reminder pointing out the importance of obtaining as many replies as possible. This reminder had on its reverse side a copy of the questions in case the original had been mislaid. The households from which no reply had been received were visited by a Health Visitor and where possible the information was obtained by interview.

Various measures were taken to encourage co-operation. Before the first letters were sent out the local press in each area generously gave publicity to the survey by printing a short description of the method and purpose of the research. Each letter was sent to the householder by name and was signed by the Chest Physician of that area. The general practitioners in each area were notified and asked to deal with any difficulties the questionnaire might cause amongst their patients.

As the questionnaires were returned from men aged 55 to 64 , they were separated according to the answer "Yes" to the question "Do you bring up phlegm like this on most days for as much as 3 months in the year?": these were called "positives" and those answering "No" were called "negatives". All "positives" who expressed willingness to attend were called to the nearest Chest Clinic. A control group of "negatives" was selected from those men willing to attend whose reply arrived by the same, or next, post as a "positive" from the same polling district. If there were several "negatives" from whcih to choose, the letters were shuffled and one was picked out. If a "negative" failed to attend, another from the same district was selected on the same day. Selection in this manner was continued during the survey in the Halesworth and Cromer to Holt area. In Peterborough all willing "negatives" were invited to attend the Chest Clinic.

To facilitate attendance the men were offered a choice of appointments, including one in the evening. Transport was provided when needed.

At each Clinic the doctor completed a full Medical Research Council Questionnaire on Respiratory
Symptoms (1960) and carried out physical examination in every case. Weight, height, and peak expiratory flow rate were recorded by the clinic nurse, and the chest was $x$-rayed.

At the time of the interview the doctor did not know the reply that had been made to the postal questionnaire by the man he was interviewing. To reduce variations in interviewing technique, the three doctors studied the instructions and amendment to instructions in the use of the M.R.C. questionnaire on respiratory symptoms (1960) approved by the M.R.C. Committee on the Aetiology of Bronchitis, and also listened to recordings of an experienced interviewer. Men were not called to the clinic from households from which no reply was received to the original or follow-up letter or which had to be visited to obtain information.

\section{RESULTS}

\section{(1) CO-OPERATION OF HOUSEHOLDERS}

A reply was obtained from 4,117 (85.8 per cent.) of the 4,798 households to which letters were sent. The response in each area was similar and the proportion of men in the age group 55 to 64 was comparable (Table I). All the 681 households from 8 which no reply was received were visited and co-operation was obtained from 575 (84 per cent.) (Table II). Altogether 4,692 replies to the letter and? health visitor's visit were obtained from the 4,798 households, an overall response of 97.8 per cent., yielding a total of 685 men in the age group 55 to

TABLE I

REPLIES TO POSTAL SURVEY

\begin{tabular}{|c|c|c|c|c|c|}
\hline \multirow[t]{2}{*}{ Area } & \multirow{2}{*}{$\begin{array}{c}\text { Letters } \\
\text { Sent }\end{array}$} & \multicolumn{2}{|c|}{ Replies } & \multicolumn{2}{|c|}{$\begin{array}{l}\text { Males aged } \\
55-64 \text { yrs }\end{array}$} \\
\hline & & No. & Per cent. & No. & Per cent. \\
\hline $\begin{array}{l}\text { Peterborough } \\
\text { Halesworth } \\
\text { Cromer and Holt }\end{array}$ & $\begin{array}{l}1,598 \\
1,596 \\
1,604\end{array}$ & $\begin{array}{l}1,381 \\
1,343 \\
1,393\end{array}$ & $\begin{array}{l}86 \cdot 4 \\
84 \cdot 1 \\
86 \cdot 8\end{array}$ & $\begin{array}{l}207 \\
191 \\
175\end{array}$ & $\begin{array}{l}14 \cdot 9 \\
14 \cdot 2 \\
12 \cdot 5\end{array}$ \\
\hline Total & 4,798 & 4,117 & $85 \cdot 8$ & 573 & $13 \cdot 9$ \\
\hline
\end{tabular}

TABLE II

RESPONSE TO FOLLOW-UP VISIT BY HEALTH VISITOR TO HOUSEHOLDS NOT REPLYING TO THE LETTERS FROM THE CLINIC

\begin{tabular}{c|c|c|c|c|c}
\hline \multirow{2}{*}{ Area } & \multirow{2}{*}{$\begin{array}{c}\text { Houses } \\
\text { Visited }\end{array}$} & \multicolumn{2}{|c|}{ Response } & \multicolumn{2}{|c|}{$\begin{array}{c}\text { Males aged } \\
\text { S5-64 yrs }\end{array}$} \\
\cline { 3 - 6 } & & No. & Per cent. & No. & Per cent. \\
\hline $\begin{array}{l}\text { Peterborough } \\
\text { Halesworth } \\
\text { Cromer and Holt }\end{array}$ & 217 & 198 & $91 \cdot 2$ & 34 & $17 \cdot 2$ \\
\hline \multicolumn{1}{c|}{ Total } & 211 & 220 & 86.9 & 41 & 18.6 \\
& 681 & 575 & $84 \cdot 4$ & 37 & $23 \cdot 5$ \\
\hline
\end{tabular}


64 (Table III). In the houses visited by the Health Visitors there was a significantly greater percentage of men in the age group 55 to 64 years $(19.5$ per cent.) compared with 13.9 per cent. in houses from which a reply was received by post.

TABLE III

RESULTS OF TABLES I AND II COMBINED

\begin{tabular}{c|c|c|c|c|c}
\hline \multirow{2}{*}{ Area } & \multirow{2}{*}{$\begin{array}{c}\text { Letters } \\
\text { Sent }\end{array}$} & \multicolumn{2}{|c|}{ Response* } & \multicolumn{2}{c}{$\begin{array}{c}\text { Men in } \\
\text { Age Group }\end{array}$} \\
\cline { 3 - 6 } \cline { 4 - 6 } & & No. & Per cent. & No. & Per cent. \\
\hline $\begin{array}{l}\text { Peterborough } \\
\text { Halesworth } \\
\text { Cromer and Holt }\end{array}$ & 1,598 & 1,579 & $98 \cdot 8$ & 241 & $15 \cdot 2$ \\
\hline Total & 1,604 & 1,563 & $97 \cdot 9$ & 232 & $14 \cdot 8$ \\
& 4,798 & 4,692 & $96 \cdot 6$ & 212 & $13 \cdot 6$ \\
\hline
\end{tabular}

\section{(2) Prevalence of Chronic Bronchitis}

The replies to the self-applied questionnaire show that in the industrial part of Peterborough 31.8 per cent. of men in the age group 55 to 64 considered they had had cough and phlegm for 3 months or more in the year; in Halesworth the incidence was 22.0 per cent. and in the Cromer to Holt district it was 24.0 per cent. The difference between the industrial area and the two rural areas is not statistically significant (Table IV). Although in the group visited by the Health Visitor (Table V) there was a significantly higher proportion of men in the 55 to 64 age group than in the postal survey, the proportion of men with symptoms is not appreciably changed by

TABLE IV

INCIDENCE OF COUGH AND SPUTUM FOR 3 MONTHS OF THE YEAR IN MEN AGED 55-64, FROM SELF-APPLIED QUESTIONNAIRE

\begin{tabular}{|c|c|c|c|c|}
\hline \multirow{2}{*}{ Area } & \multirow{2}{*}{$\begin{array}{l}\text { No. of } \\
\text { Men aged } \\
55-64 \text { yrs }\end{array}$} & \multirow{2}{*}{$\begin{array}{l}\text { Forms } \\
\text { Com- } \\
\text { pleted }\end{array}$} & \multicolumn{2}{|c|}{ Men with Symptoms } \\
\hline & & & No. & Per cent. \\
\hline $\begin{array}{l}\text { Peterborough } \\
\text { Halesworth. } \\
\text { Cromer and Holt . }\end{array}$ & $\begin{array}{l}207 \\
191 \\
175\end{array}$ & $\begin{array}{l}204 \\
186 \\
171\end{array}$ & $\begin{array}{l}65 \\
41 \\
41\end{array}$ & $\begin{array}{l}31 \cdot 8 \\
22 \cdot 0 \\
24 \cdot 0\end{array}$ \\
\hline Total $\ldots$ & 573 & 561 & 147 & $26 \cdot 2$ \\
\hline
\end{tabular}

TABLE V

INCIDENCE OF COUGH AND SPUTUM FOR 3 MONTHS OF THE YEAR IN MEN AGED 55-64 FROM QUESTIONNAIRE APPLIED BY HEALTH VISITOR

\begin{tabular}{|c|c|c|c|c|}
\hline \multirow{2}{*}{ Area } & \multirow{2}{*}{$\begin{array}{l}\text { No. of } \\
\text { Men aged } \\
\text { 55-64 yrs }\end{array}$} & \multirow{2}{*}{$\begin{array}{l}\text { Forms } \\
\text { Com- } \\
\text { pleted }\end{array}$} & \multicolumn{2}{|c|}{ Men with Symptoms } \\
\hline & & & No. & Per cent. \\
\hline $\begin{array}{l}\text { Peterborough } \\
\text { Halesworth. } \\
\text { Cromer and Holt }\end{array}$ & $\begin{array}{l}34 \\
41 \\
37\end{array}$ & $\begin{array}{l}30 \\
23 \\
28\end{array}$ & $\begin{array}{l}8 \\
2 \\
4\end{array}$ & $\begin{array}{r}26 \cdot 6 \\
8 \cdot 7 \\
14 \cdot 2\end{array}$ \\
\hline Total $\ldots$ & 112 & 81 & 14 & $17 \cdot 2$ \\
\hline
\end{tabular}

adding together the results of the postal replies and visits, giving a prevalence of $31 \cdot 2$ per cent. for Peterborough, 20.5 per cent. for Halesworth, and 22.5 per cent. in the Holt to Cromer district (Table VI).

TABLE VI

RESULTS OF TABLES IV AND V COMBINED

\begin{tabular}{|c|c|c|c|c|}
\hline \multirow{2}{*}{ Area } & \multirow{2}{*}{$\begin{array}{l}\text { No. of } \\
\text { Men aged } \\
55-64 \text { yrs }\end{array}$} & \multirow{2}{*}{$\begin{array}{l}\text { Forms } \\
\text { Com- } \\
\text { pleted }\end{array}$} & \multicolumn{2}{|c|}{ Men with Symptoms } \\
\hline & & & No. & Per cent. \\
\hline $\begin{array}{l}\text { Peterborough } \\
\text { Halesworth } \\
\text { Cromer and Holt }\end{array}$ & $\begin{array}{l}241 \\
232 \\
212\end{array}$ & $\begin{array}{l}234 \\
209 \\
199\end{array}$ & $\begin{array}{l}73 \\
43 \\
45\end{array}$ & $\begin{array}{l}31 \cdot 2 \\
20 \cdot 5 \\
22 \cdot 5\end{array}$ \\
\hline Total .. & 685 & 642 & 161 & $25 \cdot 1$ \\
\hline
\end{tabular}

\section{(3) Accuracy of a Written Self-APPlied} QUESTIONNAIRE

Table VII shows the number of men in each area who attended the clinic for interview. Of 147 "positives", 105 attended for interview. In the Peterborough area, where all the 139 "negatives" who expressed willingness to attend were sent for, 87 attended. In the Halesworth and Cromer and Holt areas, the number of "negatives" sent for was matched with the willing "positives".

TABLE VII

NUMBER OF MEN AGED 55-64 ATTENDING LOCAL CLINIC FOR INTER VIEW

\begin{tabular}{|c|c|c|c|c|}
\hline \multirow[t]{2}{*}{ Area } & \multicolumn{2}{|c|}{$\begin{array}{l}\text { Men stating they had } \\
\text { cough and sputum } \\
\text { for } 3 \text { months of the } \\
\text { year on postal } \\
\text { questionnaire }\end{array}$} & \multicolumn{2}{|c|}{$\begin{array}{l}\text { Men denying cough } \\
\text { and sputum for as } \\
\text { much as } 3 \text { months of } \\
\text { the year on postal } \\
\text { questionnaire }\end{array}$} \\
\hline & $\begin{array}{l}\text { Replied } \\
\text { by Post }\end{array}$ & $\begin{array}{c}\text { Attended } \\
\text { Clinic }\end{array}$ & $\begin{array}{l}\text { Replied } \\
\text { by Post }\end{array}$ & $\begin{array}{c}\text { Attended } \\
\text { Clinic }\end{array}$ \\
\hline $\begin{array}{l}\text { Peterborough } \\
\text { Halesworth } \\
\text { Cromer and Holt } \ldots\end{array}$ & $\begin{array}{l}65 \\
41 \\
41\end{array}$ & $\begin{array}{l}54 \\
26 \\
25\end{array}$ & $\begin{array}{l}139 \\
145 \\
130\end{array}$ & $\begin{array}{l}87 \\
28 \\
30\end{array}$ \\
\hline Total & 147 & 105 & 414 & 145 \\
\hline
\end{tabular}

Table VIII shows the agreement and disagreement between the self-applied questionnaire and the answers obtained at interview to the question "Do

\section{TABLE VIII}

AGREEMENT AND DISAGREEMENT BETWEEN SELFAPPLIED POSTAL OUESTIONNAIRE AND M.R.C. OUESTIONNAIRE COMPLETED AT CLINIC TO THE QUESTION ON COUGH AND SPUTUM LASTING FOR 3 MONTHS OF THE

\begin{tabular}{l|l|c|c|c}
\cline { 3 - 5 } \multicolumn{1}{c|}{} & \multicolumn{2}{c}{ Answer to Postal Questionnaire } \\
\cline { 3 - 5 } \multicolumn{1}{c|}{} & Positive & Negative & Total \\
\hline $\begin{array}{l}\text { Answer to M.R.C. } \\
\text { Questionnaire }\end{array}$ & Positive & 86 & 18 & 104 \\
\cline { 2 - 5 } & Negative & 19 & 127 & 146 \\
\cline { 2 - 5 } & Total & 105 & 145 & 250 \\
\hline
\end{tabular}


you cough up sputum for as much as 3 months of the year?" Of the 250 men who attended and completed the questionnaire, $213(85.2$ per cent.) gave the same reply to this question on each occasion but in 37 cases (14.8 per cent.) the answers differed. In 26 instances the difference was due to the man's doubting whether his phlegm persisted for 3 months (Table IX). Ten men who had stated they had phlegm for 3 months each year on the self-applied questionnaire, later denied this when answering the doctor. Only one person who stated he did not have this symptom later claimed to have it when asked by the doctor.

\section{TABLE IX}

ANALYSIS OF CHANGES IN ANSWERS BETWEEN SELFAPPLIED POSTAL OUESTIONNAIRE AND M.R.C. QUESTIONNAIRE APPLIED BY CLINIC PHYSICIANS AT A LATER DATE (Total attendance 250)

\begin{tabular}{|c|c|c|c|}
\hline \multicolumn{2}{|c|}{$\begin{array}{l}\text { Reasons for answers indicating "no bronchitis" } \\
\text { in one or other questionnaire }\end{array}$} & \multirow{2}{*}{$\begin{array}{r}\text { No. } \\
8 \\
1 \\
10\end{array}$} & \multirow{2}{*}{$\begin{array}{c}\begin{array}{r}\text { Per } \\
\text { cent. }\end{array} \\
3 \cdot 2 \\
0 \cdot 4 \\
4 \cdot 0\end{array}$} \\
\hline $\begin{array}{l}\text { A. In persons } \\
\text { changing from } \\
\text { positive to } \\
\text { negative }\end{array}$ & $\begin{array}{l}\text { (1) Definite symptoms, but } \\
\text { duration in doubt } \\
\text { (2) Minimal symptoms, dura- } \\
\text { tion in doubt } \ldots \\
\text { (3) Now denying phlegm } \quad \text {.. }\end{array}$ & & \\
\hline & Total & 19 & $7 \cdot 6$ \\
\hline \multirow[t]{2}{*}{$\begin{array}{l}\text { B. In persons } \\
\text { changing from } \\
\text { negative to } \\
\text { positive }\end{array}$} & $\begin{array}{l}\text { (1) Definite symptoms, but } \\
\text { duration in doubt } \\
\text { (2) Minimal symptoms, dura- } \\
\text { tion in doubt } \ldots \\
\text { (3) Denying phlegm at first... }\end{array}$ & $\begin{array}{r}11 \\
6 \\
1\end{array}$ & $\begin{array}{l}4 \cdot 4 \\
2 \cdot 4 \\
0 \cdot 4\end{array}$ \\
\hline & Total & 18 & $7 \cdot 2$ \\
\hline
\end{tabular}

\section{(4) Comparison of Clinical Diagnosis with} Diagnosis based on SyMPTOMS AlONE

After completing the Medical Research Council's questionnaire and examining each selected man, the doctor gave his opinion whether that person had chronic bronchitis or not. This clinical opinion is compared with the answer to the question relating to persisting cough and sputum in the postal questionnaire (Table X).

TABLE X

AGREEMENT AND DISAGREEMENT BETWEEN REPLIES TO OUESTION ON PERSISTING COUGH AND SPUTUM ON SELF-APPLIED POSTAL QUESTIONNAIRE AND DOCTOR'S DIAGNOSIS OF CHRONIC BRONCHITIS

\begin{tabular}{l|c|c|c|c}
\cline { 3 - 4 } & \multicolumn{3}{|c}{$\begin{array}{c}\text { Answer to Postal } \\
\text { Questionnaire }\end{array}$} \\
\hline $\begin{array}{c}\text { Doctor's } \\
\text { Diagnosis }\end{array}$ & Positive & Negative & Total \\
\hline & Negative & 45 & 4 & 64 \\
\hline & Total & 105 & 141 & 186 \\
\hline
\end{tabular}

It will be seen that, of the 105 men with persistent productive cough, sixty were diagnosed clinically as having chronic bronchitis and only four of the 145 men without this symptom were so diagnosed.

Of the 45 men who said that they had chronic cough and phlegm on the postal questionnaire, and who on clinical examination were considered not to be suffering from chronic bronchitis, 29 (64.4 per cent.) said they had a stuffy nose or nasal catarrh for as much as 3 months each year (Table $\mathrm{XI})$. This compares with a prevalence of 44.5 per cent. in the whole group examined at the Clinic (111 out of $250-44.4$ per cent.). This suggests either, that some men did not comply with the advice on the questionnaire "Do not count phlegm from the nose", or that in some cases a productive cough which the patients reported on the postal questionnaire was interpreted by the doctors as the result of nasal catarrh rather than of true bronchitis. The question of what part upper respiratory catarrh plays in the aetiology of chronic bronchitis is not a matter for this paper.

\section{TABLE XI}

REPLIES TO QUESTION ON PERSISTING NASAL CATARR GIVEN AT INTERVIEW, IN PATIENTS WITH AND WITHOU CHRONIC BRONCHITIS AS DIAGNOSED BY DOCTOR

\begin{tabular}{|c|c|c|c|c|c|c|}
\hline $\begin{array}{c}\text { Doctor's } \\
\text { Diagnosis }\end{array}$ & $\begin{array}{l}\text { No. of } \\
\text { Cases }\end{array}$ & $\begin{array}{l}\text { Reply t } \\
\text { Question } \\
\text { cerning } \\
\text { Ph }\end{array}$ & $\begin{array}{l}\text { Postal } \\
\text { aire con- } \\
\text { ugh and } \\
g \mathrm{gm}\end{array}$ & Nas & al $\mathbf{C}$ & atarrh \\
\hline Bronchitic & 64 & $\begin{cases}+ \text { ve } & 60 \\
-v e & 4\end{cases}$ & $\begin{array}{c}93.5 \% \\
6.5 \%\end{array}$ & $\begin{array}{l}+\mathrm{ve} \\
-\mathrm{ve} \\
+\mathrm{ve} \\
-\mathrm{ve}\end{array}$ & $\begin{array}{r}35 \\
25 \\
2 \\
2\end{array}$ & $\begin{array}{l}58.4 \% \\
41.6 \% \\
50.6 \% \\
50.6 \%\end{array}$ \\
\hline Non- & 186 & $\begin{cases}+ \text { ve } & 45 \\
- \text { ve } & 141\end{cases}$ & $\begin{array}{l}24 \cdot 2 \% \\
75 \cdot 8 \%\end{array}$ & $\begin{array}{l}+ \text { ve } \\
\text { - ve } \\
+ \text { ve } \\
\text { - ve }\end{array}$ & $\begin{array}{l}29 \\
16 \\
45 \\
96\end{array}$ & $\begin{array}{l}64.4 \% \\
35.6 \% \\
32.0 \% \\
68.0 \%\end{array}$ \\
\hline
\end{tabular}

The clinical findings in the men questioned and examined at Chest Clinics will be studied and analysed in a further paper to be published later.

\section{Discussion}

Surveys of the prevalence of respiratory symptoms and chronic bronchitis have been carried out in several industrial and rural areas in Great Britain (Higgins, Oldham, Cochrane, and Gilson, 1956; Higgins and others, 1959; Higgins, 1957; Higgins and Cochran, 1958). Table XII (opposite) compares these results with those obtained in East Anglia. In rural areas the percentage of men aged 55-64 with persistent productive cough was 22.5 per cent. in the Holt-Cromer district and 20.5 per cent. in Halesworth. Comparable results obtained 
TABLE XII

PREVALENCE OF PERSISTING PRODUCTIVE COUGH, AND OF "BRONCHITIS" DEFINED AS PERSISTENT COUGH AND PHLEGM AND A CHEST ILLNESS IN THE PAST 3 YEARS IN VARIOUS SURVEYS

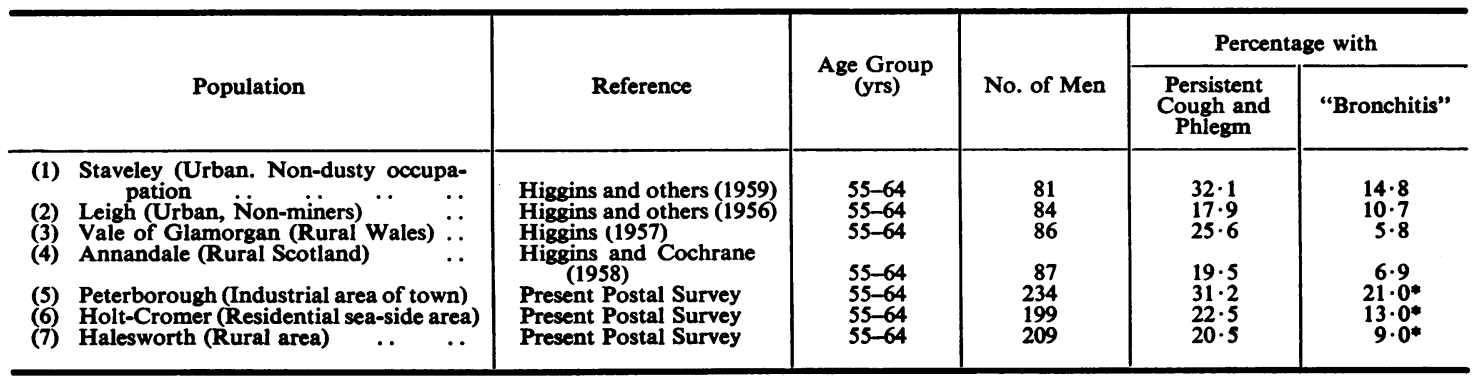

- Figures obtained from those who attended the clinic (see Table XIII).

by Higgins and his colleagues were 25.6 per cent. in a rural area of Wales and 19.5 per cent. in a rural area in Scotland. In industrial areas, this symptom occurred in 31.2 per cent. of men in Peterborough (pop. 62,270 approx.), similar to the $32 \cdot 1$ per cent. of men in non-dusty occupations in Staveley, Derbyshire (pop. 1,800 approx., Higgins and others, 1959). In Leigh, Lancashire (pop. 46,380 approx.) the prevalence was 17.9 per cent. in non-miners (Higgins and others, 1956). It should be noted that in the survey by Higgins the population is divided into occupational groups.

Table XII also shows figures for the prevalence of chronic bronchitis in these areas of East Anglia and results obtained in previous surveys. However, these figures cannot be regarded as comparable because, in the surveys carried out by Higgins, chronic bronchitis is defined as the constant production of phlegm and one or more chest illnesses during the previous 3 years, and the men were asked if they brought up phlegm "throughout the year"; while in the present survey they were asked if they brought up phlegm "for as much as 3 months each year".

In this survey the prevalence of "bronchitis" in the urban area is 21 per cent., in the combined rural areas 12.8 per cent, giving an urban : rural ratio of 1.6:1 (Table XIII).

The College of General Practitioners Survey (1961) of men aged 40-64 showed an urban: rural ratio of $2 \cdot 3: 1$, using a standard diagnosis and comparing urban districts and municipal boroughs with rural districts; though if county and metropolitan boroughs were compared with rural districts the ratio was much greater, $4 \cdot 4: 1$. The difference in bronchitis mortality between urban and rural areas is about 2:1 in men (Registrar General, 1954). The impression of Chest Physicians in East Anglia that

\section{TABLE XIII}

PREVALENCE OF CHRONIC BRONCHITIS DEFINED AS COUGH AND PHLEGM PERSISTING FOR MORE THAN 3 MONTHS OF THE YEAR AND A CHEST ILLNESS DURING THE PAST 3 YEARS, IN THE THREE AREAS SURVEYED

\begin{tabular}{c|c|c|c}
\hline \multirow{2}{*}{ Area } & No. who attended \\
the Clinic & \multicolumn{2}{|c}{$\begin{array}{c}\text { Prevalence of } \\
\text { Bronchitis }\end{array}$} \\
\cline { 2 - 4 } & & No. & Per cent. \\
\hline $\begin{array}{l}\text { Peterborough } \\
\text { Halesworth }\end{array}$ & 141 & 30 & 21 \\
Cromer-Holt & 54 & 7 & 13 \\
\hline
\end{tabular}

chronic bronchitis is common in their rural areas has been confirmed.

To give reliable information, a survey of prevalence depends on the degree of co-operation of the population, the accuracy of the answers to the questionnaires and the method of sampling, which in this survey was decided by the statistician.

The co-operation of the public in the areas chosen was very satisfactory, as 85.8 per cent. of households replied to the letter sent to them. In these houses, of 573 men in the age group, 561 (97.9 per cent.) completed and returned the questionnaire. On the postal survey alone, amongst 685 men aged 55-64 in the sample of the population surveyed, only 18 per cent. failed to complete a questionnaire. This compares with a default rate of approximately 25 per cent. among the maintenance staff of the London Transport Executive at Chiswick and Acton in returning a similar questionnaire (Fletcher and Tinker, 1961). It is considered that the measures taken to encourage co-operation contributed to this good response, and in particular the carefully worded letters of inquiry. By later visiting the homes from which no reply was received, co-operation was received from no less than 97.8 per cent. of the sample of population surveyed and questionnaires 
completed by 93.8 per cent. ( 642 of 685 ) of men in the age group. This confirms the opinion of Fletcher and Tinker (1961) that a self-applied questionnaire with a follow-up visit to defaulters might be an economical and reliable technique.

In this survey an estimate of the accuracy of the self-applied questionnaire is obtained by comparing it with a similar questionnaire applied by a doctor at a clinical interview. To the question "Do you cough up sputum for as much as 3 months of the year", 85 per cent. gave the same reply on both occasions. This compares with 74 per cent. agreement between the verbal and written questions on phlegm production in London Transport Executive workers (Fletcher and Tinker, 1961). It is shown that 95.6 per cent. of replies were consistent regarding the presence or absence of productive cough; it was the duration of this symptom which was sometimes uncertain.

The method of survey employed was only decided upon after preliminary trials. A pilot survey based on house-to-house visiting in three areas near Ipswich was satisfactory. All adults in the houses visited were asked questions 1 to 10 of the M.R.C. Questionnaire, and those who gave positive answers asked to attend the clinic. The following conclusions were reached:

(1) Evening visiting was essential.

(2) To achieve satisfactory clinic attendance the times of appointment must be convenient and transport provided when needed.

(3) The number of hours worked per hundred interviews could be as little as $15 \mathrm{hrs}$ in one area or as much as $50 \mathrm{hrs}$ in another.

After this a larger survey was started in Peterborough which planned to obtain a 1 in 10 sample of men in the age group and yield about eighty men with respiratory symptoms. However, progress was slow because of a difficult interviewing procedure involving much travelling, as the households were visited in a random order and not by proximity, and this survey was not completed.

Following the report of Fletcher and Tinker (1961), a pilot trial of a self-applied questionnaire was undertaken. Letters were sent to one hundred randomly selected addresses in each of three areas, in Peterborough, Clay (Norfolk), and Felixstowe. A good response of 77 per cent. replies was obtained, and in one area follow-up visiting of non-cooperating households increased the response to 99 per cent., and this encouraged us to use this technique in the main survey.

\section{SUMmary}

A survey of the prevalence of bronchitis in differing areas of East Anglia is reported for men aged 55 to 64 years.

The survey was conducted by means of a selfapplied questionnaire sent by post to randomlyselected addresses accompanied by a carefullyworded explanatory letter.

Follow-up letters were sent to houses from which no reply was received, and follow-up visiting of these houses was later carried out by Health Visitors.

Co-operation was obtained from 98 per cent. of some 4,800 houses approached, and nearly 700 men in the age group were found, amounting to 15 per cent. of the men who replied from the selected houses. Bronchitis symptoms in the age group studied were found to occur in about one in three men in the industrial area, and in one in five men in the other areas.

The Survey was undertaken by the Chest Consultants' Advisory Committee of the East Anglian Regional Hospital Board. The co-ordinators were Dr G. R. McNab and $\mathrm{Dr} \mathrm{M}$. Greenberg, assisted by Mr V. Minter of the Regional Hospital Board. The survey was financed by the East Anglian Regional Hospital Board on the advice of their Clinical Research Committee.

The staff undertaking the field work and clinical assessments at each of the three centres were:

\begin{tabular}{|c|c|c|c|}
\hline Staff & Peterborough & Holt and Cromer & Halesworth \\
\hline Physicians & Dr G. B. Royce & Dr J. Slator & Dr D. P. F. Embleton \\
\hline Clinic Nurses & B. E. Walker & $\begin{array}{l}\text { M. L. Bryce } \\
\text { M. Travers }\end{array}$ & E. Platt \\
\hline Radiographers & - & $\begin{array}{l}\text { Mr G. Pallister } \\
\text { M.S.R., S.R.R. }\end{array}$ & Miss N. Wilkinson \\
\hline Health Visitors & - & $\begin{array}{l}\text { Mrs St. Claire-Vernon } \\
\text { Miss W. A. Bryan } \\
\text { Miss M. G. Swann } \\
\text { Mrs V. N. T. Carter }\end{array}$ & $\begin{array}{l}\text { Miss S. J. Williams } \\
\text { Miss M. A. Beeton } \\
\text { Miss L. Luff }\end{array}$ \\
\hline Clerks & $\begin{array}{l}\text { Miss H. W. Johnson } \\
\text { Mrs A. J. Gibbs }\end{array}$ & $\begin{array}{l}\text { Mrs L. Hipwell } \\
\text { Miss H. Carradice } \\
\text { Mrs F. Gledhill } \\
\text { Miss J. Gould } \\
\text { Mr G. Stibbons }\end{array}$ & $\begin{array}{l}\text { Mr G. L. Gibson } \\
\text { Mrs J. Holden }\end{array}$ \\
\hline
\end{tabular}


Mr R. G. Carpenter and Miss E. Dalton of the Statistical Unit of the Department of Human Ecology, Cambridge, advised on the sampling of the populations and arranged for the statistical analysis of the results.

The report was prepared by Dr J. Slator with the assistance of Dr G. R. McNab and Dr C. J. Stewart.

The Committee thank the following for advice and assistance with the conduct of the survey: Dr C. $M$. Fletcher, of the Post-graduate Medical School of London, Dr J. B. Ewen, Senior Administrative Medical Officer of the East Anglian Regional Hospital Board, Dr S. T. Gray, Medical Officer of Health of East Suffolk, and Dr K. F. Alford, Medical Officer of Health of Norfolk.

\section{REFERENCES}

College of General Practitioners (1961). Brit. med. J., 2, 973.

Fletcher, C. M., and Tinker, C. M. (1961). Ibid., 1, 1491. Higgins, I. T. T. (1957). Ibid., 2, 1198.

- and Cochran, J. B. (1958). Tubercle (Lond.), 39, 296. , Cochrane, A. L., Gilson, J. C., and Wood, C. H. (1959). Brit. J. industr. Med., 16, 255.

, Oldham, P. D., Cochrane, A. L., and Gilson, J. C. (1956). Brit. med. J., 2, 904.

Registrar General (1954). "Statistical Review of England and Wales, 1953." H.M.S.O., London.

\section{APPENDIX A}

\section{STATISTICAL METHOD OF SELECTION}

In the Peterborough and Cromer areas, which were each subdivided into eight, addresses to which letters were sent were selected by generating a list of random numbers corresponding to those for persons on the electoral roll. A particular address was included only if the elector with a given random number was the first one listed at that address. The number of addresses selected in each sub-area was proportional to the number of names on the electoral roll for that area, and such that (approximately) 1,600 addresses were selected in each of the main areas. (The number 1,600 was used because in a pilot survey a health visitor had found that at 1,600 addresses there would be about 250 men in the age group 55-64, of whom approximately thirty would be positive.)

In the Halesworth area it was planned that every household should receive a letter.

\section{APPENDIX B \\ EAST ANGLIAN REGIONAL HOSPITAL BOARD BRONCHITIS SURVEY}

-If you are a man aged from 55 to 64 please complete this form:-

(I) Write your name and address and date of birth in correct places below.

(2) Answer each question below by putting a cross in the correct square marked "yes" or "no" like this

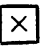

(3) Return the paper in the stamped addressed envelope sent with it.

Surname. First Names.

Date of Birth.

Address. 
COUGH: When you answer questions $a, b, c, d$, and e, do not count throat clearing or a single cough in the morning.

a. Do you usually cough first thing in the morning in winter?
b. Do you cough with your first smoke in winter?
c. Do you cough on first going out of doors in winter?

d. Do you usually cough during the day or at night in the winter? (Do not count an occasional cough)...

e. Do you cough like this on most days for as much as three months each year? ...

PHLEGM: When you answer questions $f, g, h$, and $i$, do not count phlegm from the nose, but do count swallowed phlegm.

f. Do you usually bring up any phlegm from your chest first thing in the morning

Yes in winter?

g. Do you usually bring up any phlegm from your chest with your first smoke in the morning in winter?

h. Do you usually bring up any phlegm from your chest on first going out of doors in the winter?

i. Do you bring up any phlegm from your chest two or more times during the day or night?

j. Do you bring up phlegm like this on most days for as much as three months in the year?

k. Would you be willing to attend a Chest Clinic for $X$-ray examination (even if you have no cough or phlegm?) 